\title{
Is it Labor's Turn to Globalize? Twenty-first Century Opportunities and Strategic Responses
}

\author{
Peter Evans, University of California at Berkeley
}

\begin{abstract}
Neoliberal globalization is commonly seen as the nemesis of labor. A counter-thesis is offered here. Neoliberal capitalism threatens labor at every level, from the local to the national to the global, but rather than assuming that the global level is labor's Achilles heel, it makes sense to explore how mobilization at the global level can contribute to contestation at the local and national level. Like any reorganization of production, global neoliberal capitalism creates opportunities for counter-organization. Capital is thoroughly globalized. Could it now be labor's turn? Labor's response to these opportunities has involved an interconnected diversity of mutually reinforcing organizational forms and strategies. They range from restructured global confederations to new networks of transnational labor NGOs to new orientations toward the global arena on the part of national unions. Synergies among old and new organizational forms have the potential to make the twenty-firstcentury 'labor's turn to globalize.'
\end{abstract}

\section{KEYWORDS}

globalization, global unions, neoliberalism, transnational alliances

\section{Is it Labor's Turn to Globalize? Twenty-first Century Opportunities and Strategic Responses ${ }^{1}$}

An audacious vision is starting to compete with lamentations that neoliberalism and globalization have destroyed the labor movement. In this vision, the rise of global neoliberal capitalism has created structural opportunities, giving labor new incentives and leverage to organize globally. Global corporations give far-flung workers common targets. Corporate organizational structures provide road maps for the spread of global campaigns. Neoliberal tropes of universal rights can be turned against capital, bolstering workers' confidence that their struggles for dignity and collective organization are at the global political forefront. Far from being the death knell of the labor movement, global neoliberal capitalism gives the 
labor movement a new opportunity to realize old dreams of transcending parochial identities and national boundaries.

This is not just a theoretical vision. It has seeped into the repertoires of organizers trying to win campaigns on the ground. Union organizers who saw global campaigns as largely irrelevant 25 years ago now see them as a crucial tool. As Steven Lerner, former director of SEIU's Property Services Division, put it (2007b: 17), 'Contrary to conventional wisdom, the spread of multinational corporations and the increasing concentration of capital have created the conditions that can turn globalization on its head [...]'.

Has the globalization of capital opened the way for labor to take its turn to globalize? Is the resurgence of interest in building global organizations and strategies a harbinger that labor's turn has finally come? It is too soon to tell, but one conclusion is incontrovertible. If labor were to successfully construct a set of effective global campaigns and institutions, the implications for global politics and social change would be profound. Kate Bronfenbrenner (2007: 225) puts the case bluntly: 'a united global labor movement is the single greatest force for global social change.'

Equally incontrovertible is the stubborn resistance that efforts to explore possibilities for building global labor movement will face, not only as practice, ${ }^{2}$ but also as a theoretical enterprise. Resistance from followers of the 'liberal creed' who celebrate labor's decline as essential to the construction of 'efficient' global markets goes without saying. Less obvious, but equally powerful, is resistance from disillusioned theorists on the left. As Jane Wills (1998: 112) has pointed out, pessimistic assessment of labor's prospects in a globalized world had already become 'something of an orthodoxy in much academic debate' at the end of the twentieth century. Currently, those who have chosen 'uncompromising pessimism' as the only legitimate intellectual stance see anyone not dismissive of the potential for building global labor solidarity as a 'Pollyanna'. ${ }^{3}$

Lamentation over the consequences of neoliberal globalization, like any pessimistic position, is not hard to defend, but pessimistic positions are bad lenses for capturing possibilities for transformation. Surmounting pessimism is more likely to expose avenues for progressive change. An old example remains a good one. Acutely conscious of the structural obstacles to change in the Latin America of their day, F.H.Cardoso and Enzo Faletto refused to abandon their belief in the potential for 'collective action guided by political wills that make work what is structurally barely possible' (1979: 176) and helped fuel the theoretical imaginations of a generation of Latin Americans. ${ }^{4}$ Trying to understand how to 'make work what is structurally barely possible' is a good description of the task of assessing labor's current efforts to globalize.

The underlying argument for structural opportunity draws on old roots. It reprises Marx's foundational proposition that any reorganization of production creates new opportunities for counter-organization, and follows along the trail recently blazed by Beverly Silver (2003) from this foundational proposition to an analysis of the contemporary global political economy. In this perspective, if globalization is a central feature of the contemporary transformation of capitalism, it is likely to create global opportunities for counter-organization at the global level. 
From structural opportunity the analysis moves to possibilities for strategic response. The central proposition here is that the effectiveness of labor's response does not rest on the invention of a single organizational form or campaign strategy but on the interconnections among different forms.

Labor faces a range of disparate challenges depending on the kind of capital it confronts and the political context in which the confrontation takes place. The need for diverse organizational forms follows from the diversity of challenges, but diversity of organizational forms in itself can be a disadvantage unless they can be connected. To succeed, a global labor movement would have to build a range of mutually reinforcing organizational forms and strategies, reflecting both the diversity of labor's relations to global capital and the necessity of coordinated effort across sectors and political boundaries. In short, linking together diverse organizations in ways that are strategically effective, building what might be called 'strategically concatenated diversity', is the key to enabling labor to globalize.

I will begin the analysis of structural opportunity by questioning arguments that neoliberal globalization is labor's nemesis and then present the counter-thesis that neoliberal globalization creates a new set of opportunities. Having outlined the case for opportunity, I will turn to the prospects for response. I will survey the labor movement actors currently trying to take advantage of these opportunities, moving from the traditional formal structures of the global union movement through the new transnational labor networks built on NGO-union alliances to the spreading involvement of national unions and confederations in transnational campaigns.

If the overall argument is successful it will contribute to moving discussion of the global arena out of the realm of lamentation and in the direction of a more productive debate over how the global arena can most effectively be transformed from a threat to a resource that complements and strengthens national and local contestation. Instead of dismissing the global arena as the terrain that capital uses to checkmate national or local advances, this debate would be about whether and how the global arena can become a resource for countering the decline of labor's power at the local and national level.

\section{Questioning Arguments for Neoliberal Globalization as Labor's Nemesis}

Three varieties of argument underlie the thesis that neoliberal globalization is the nemesis of the labor movement: an economic argument, a socio-cultural argument and a political argument. Each sets out a plausible claim, but each is based on a partial and therefore misleading reading of the contemporary global political economy.

The economic argument is simple: the accelerated mobility of capital, the geographic dispersion of production and the expansion of trade all increase the bargaining power of capital and intensify competition among workers in different countries, especially competition between workers in rich countries and those in poor countries. Most simply neoliberal globalization is seen as the nemesis of a global labor movement because global 
corporations can use the 'geography of jobs' to 'whipsaw' workers in both North and South by shifting production from one geographic site to another.'

The 'geography of jobs' argument is prominent not only because of its Darwinian elegance but also because the effects of capital mobility are disproportionately salient for the traditional manufacturing unions that formed the mid-twentieth century core of the labor movement. The argument is, nonetheless, less powerful than its economistic simplicity would make it appear. Capital's persistent drive to reduce the number of workers needed to produce tangible goods is continually shrinking the global pool of manufacturing jobs in both North and South, pushing most workers into place-based, non-tradable services or the informal sector (see Evans and Staveteig 2009). Only a minority of workers now produces the tradable manufactured goods that give them the 'privilege' of being whipsawed.

Even among the remaining producers of tradables, the threat of global re-location of jobs is only one element of capital's effort to undermine labor's rights and returns. 'Domestic whipsawing' (e.g. moving jobs from North to South in the United States, South to North in Brazil or East to West in China) may be a more potent threat in practical terms. Even more potent, at least in the Global North, are political attacks on industrial workers built on claims that they represent a privileged elite that is somehow getting 'more than its share' at the expense of consumers and low-paid service workers. Combating the threat of whipsawing must be a central element in any global labor agenda, but shifts in political power at the national level are more of a threat than changes, actual or potential, in the geography of jobs.

The socio-cultural component of the nemesis thesis relies on a different logic. Labor mobilization requires 'cultures of solidarity' and shared social networks (Fantasia 1989). Traditionally, the socio-cultural foundations of solidarity have been associated with geographic proximity and participation in the life of a geographically defined community. Global labor solidarity depends on construction of shared cultures and networks connecting workers divided by vastly different histories, lived experiences and culture, including racism and other cultural legacies of colonialism and imperialism. The socio-cultural argument starts, then, from the reasonable premise that expanding the geographic scope of labor mobilization magnifies socio-cultural divisions among workers and intensifies the difficulty of constructing shared visions and strategies.

As in the case of economic arguments, taking the socio-cultural argument beyond its simple initial logic turns it into a more debatable thesis. Immediate geographic proximity has not been sufficient for successful labor campaigns for a long time. For at least a century, effective solidarity has depended on bridging the gap between mobilization at the local level and organization at the national scale necessary to confront capital. Cultural fragmentation and parochial divisions were formidable obstacles to building solidarity at the national level. Are the workers who now are trying to build a global labor movement more culturally divided than those who built national movements a hundred and fifty years ago? Perhaps, but this argument must be considered a debatable proposition, not a foundational assumption. 
Finally, the nemesis thesis has a political argument. Since labor movement success depends on using the state to countervail the power of capital (Tilly 1995), the possibility of labor responding politically is undercut by the shift to the 'stateless' global arena. If capital generates its power in a global arena where there is no effective state apparatus, or at least no state apparatus that combines effectiveness with democratic accountability, then labor has been robbed of a key political instrument. ${ }^{6}$

Like economic and socio-cultural arguments, these political arguments rely on a partial capture of historical dynamics at the national and global level. Of course, labor movements depend on predictable, rule-bound governance even more than capitalists do. They need solid governance institutions as counterparts. And, of course, they depend on some level of democratic accountability to counter the economic power of capital. These assumptions are unquestionable. What is questionable is whether the pre-neoliberal era was one in which national state apparatuses were dependable allies for labor.

Historical moments in which national state apparatuses have been dependable allies for labor are more exceptions than the rule. Indeed, such moments can be easily interpreted as consequences of effective labor mobilization rather than causes of successful contestation. ${ }^{7}$ The Tilly (1995) vision of the state as essential ally may be plausible for mid-twentieth century European social democracies, but state as ally to capital and implacable adversary to labor is the more familiar role in the Global South (and the United States). ${ }^{8}$ In the Global South colonial regimes were doubly hostile to labor since labor was an important component of nationalist struggles. The creation of independent nationalist regimes may have been another moment in which the nation state was an ally, but the authoritarian regimes that replaced them were not. Even when the state helped implement labor demands, as in the Import Substituting Industrialization period in Latin America, it was responsive to only a small proportion of the labor force. In short, equating neo-liberal globalization with the loss of the state as ally is a dubious proposition. ${ }^{?}$

On closer examination, none of the specific logics invoked by nemesis arguments, whether economic, socio-cultural, or political, offer compelling grounds for assuming that neoliberal globalization has closed off the possibility of building a global labor movement. There is plenty of analytical space for constructing a counter-thesis. The most audacious version of the counter-thesis runs roughly as follows: Globalization, both as the generic shrinking of geographic and social space and in the form of the specific structures of the contemporary neoliberal capitalist political economy, stimulates and facilitates the mobilization of labor solidarity at the transnational level as well as the construction of transnational labor movement organizations and networks.

In order to make this counter-thesis seem less implausible, it is worth considering what a similarly audacious thesis might have looked like 150 years ago. As the organization of production was becoming more thoroughly dominated by national corporations, an 'uncompromising pessimist' might have argued that labor would be unable match the new scale at which capital was now organized. The prediction that labor would be able to use the organizational structures of national corporations and the political apparatus of the nation state to further its ends might have seemed unrealistically optimistic. Yet, powerful national 
movements eventually emerged from the fragile foundations created by oft defeated and nationally marginal labor struggles. The current scale shift is different in fundamentally important ways but assuming negative outcomes without thoroughly assessing the positive possibilities contained in such a massive change would be foolish.

\section{THE POTENTIAL FOR NEW STRUCTURAL AND IDEOLOGICAL FOOTINGS}

The thesis that neoliberal globalization creates new possibilities for building a global labor movement turns the logic of the nemesis thesis on its head. It extracts potential opportunities from current cultural and economic vectors of change and the new political patchwork of global governance. It begins with the obvious: the revolutionary reduction in the cost and difficulty of transnational communication makes building any kind of transnational network easier.

The new ease of communication with other workers around the world is a gift of generic globalization to the labor movement, just as it is to other transnational social movements. Without the possibility of almost free global communication via the Internet, myriad new transnational labor organizations, from the Southern Initiative on Globalization and Trade Union Rights (SIGTUR), to the Rio Tinto Global Union Network, to the Latin American Network for Multinational Company Research (RedLat), would have been nearly impossible to construct. Labor is only beginning to figure out how to fully exploit the newly available tools of global communication, but their presence transforms the potential for building a global movement.

Global communication technologies are more than just tools - they also reshape cultural possibilities. Contemporary global diffusion of everything from ideological presuppositions to everyday practices doesn't erase divisions, but twenty-first century workers may share as much culture at the global level as nineteenth century workers did at the national level. The global media may be a frightening Leviathan, but the memes they create are shared by workers around the world. In the workplace, the global spread of corporate structures and practices creates shared cultural milieus that permeate workers' lives almost regardless of geographic distance and political boundaries. If the socio-cultural nemesis thesis argues that cultural divisions undercut the possibility of transnational solidarity, the 'labor's turn' thesis argues that revolutionary changes in communication combine with the emergence of a globally-shared culture and everyday practices to create new potential for building solidarity across even the widest geographic divides.

The spread of universalizing neoliberal ideologies extolling 'democracy' and 'freedom' is a more ambiguous gift. These universalizing ideologies embody contradictory possibilities, including the Orwellian potential to turn them into tools for oppression. The cynical perversion of the emancipatory elements of classical liberal theory has been thoroughly unmasked (e.g. Harvey 2005, Somers 2009), but this ideology is a more doubleedged sword than its elite promulgators might hope.

Neoliberal (and classical liberal) privileging of individual agency over collective action is indeed ideologically inimical to the political culture that labor needs to counter the 
power of capital. ${ }^{10}$ Nevertheless, the global diffusion of ideological frames that assert the universal right of all human beings to being treated with dignity and to having democratic control over collective rule making is hardly a gift to capital. The very thoroughness with which these ideologies have been spread to every corner of the globe makes them powerful collective tools for shaping common agendas, building cross-border solidarities and making claims on those in power who profess to believe in them. They are as much a part of labor's new global playing field as the technological effects of globalization and, despite their abuse, they can give labor a powerful discursive advantage, especially in contexts where overt state repression is the major obstacle to mobilization.

Economically, globalized production gives capital new opportunities for threatening labor, but the global transformation of the structure of employment may eventually trump capital's advantage. Even though some service sector jobs (such as call centers) have become geographically mobile, the global shrinking of manufacturing jobs and the growth of service sector jobs in areas like health and education have created a global workforce in which 'placebased' employment dominates. For the growing proportion of jobs, in both North and South, in which cross-border competition is not an issue there is no structural conflict of interest based on the 'geography of jobs' to stand in the way of global solidarity.

Teachers, nurses, and security guards in Mexico aren't competing with teachers, nurses, and security guards in South Africa, and they all have something to gain by fighting the globally-promoted public policies that disadvantage workers in both countries and by confronting the global corporations that increasingly determine service sector working conditions in both countries. While it may seem paradoxical, the global growth in the share of 'place-based' service jobs creates new structural openness to transnational alliances.

Even the structures of global corporations are double-edged sources of power. As Lerner's argument (above) indicates, they are not simply threats but also contain new sources of leverage. Most obviously, they create incentives to increase the scale of labor's mobilization. When local actions affect such a small part of corporate profits that they are doomed to failure, regardless of how militant or well organized, the premium on building organizations with scope commensurate with those of corporate opponents becomes painfully obvious. As the labor movement responds to the obvious incentives to focus more at a global level, interesting opportunities emerge.

'Whipsawing' shifts production to locales where labor is weak in order to undercut the position of labor where it is strong, but global corporate organization also creates possibilities for 'Reverse Whipsawing'. Workers who face repression and political exclusion can be connected with workers in locales where the balance of power is more favorable. The vulnerability of corporations to campaigns in locales where labor is stronger can be used to create pressure on capital in locales where corporate power is unchecked.

The political shifts created by neoliberal globalization also contain opportunities along with threats. To be sure, the increased ability of nation states to claim that their 'hands are tied' by 'global markets' and thereby escape accountability is a political loss (Evans 1997), but, given the nation state's always dubious quality as an ally, this is not an unmitigated loss. As neoliberal globalization reduces the likelihood of state support, it also forces national 
labor movements to wean themselves from illusions that national loyalty might protect them from the power of capital. In the Global South, the necessity of changing global power relations in order to secure workers' rights locally is more harshly apparent, as local workers are undercut by policies demanded by global rule-makers, Northern governments and 'the markets.' Even in the global North, efforts to shift decision-making away from representative institutions to venues where only capital has access create new incentives for transnational solidarity (cf. Kay 2005, 2010).

Global economic governance institutions are harder to hold accountable, but they are more politically vulnerable. Organizations like the World Bank and the IMF have none of the political charisma that allows national states to deflect critiques of anti-labor policies. These institutions can't even count on the support of private capital (Evans and Finnemore 2001, Meltzer 2000). They are easy targets for cross-class campaigns (Smith 2008). At the same time, they are still public institutions and therefore politically accountable in a way that private capital is not. In short, the increasing policy role of these global institutions has given labor political targets that are the more vulnerable than national governments and easier to hold accountable than global corporations.

As global governance organizations, national governments in the North and global corporations construct a more globally homogeneous policy environment, citizens in disparate national environments face a similar set of battles over rules and policies. Shared global policy frameworks make it easier for labor movements to define a common agenda that transcends national boundaries. Comprehending other people's fights in distant venues and identifying with them becomes easier. In short, neoliberal global governance inadvertently contributes to transnational cultures of solidarity.

The revolution in communications technology, the global spread of shared culture, including universalizing ideologies of human rights, changing patterns of employment and global corporate structures, and the globalization of the policy environment can all be read as providing new structural opportunities for globalizing the labor movement. Recognizing global opportunities does not mean ignoring the continued centrality of political struggles at the national level or the local foundations on which national contestation is grounded. It does mean paying attention to the global arena as a potential source of strategic advantage rather than using it as the master explanation for decline.

Recognizing the existence of new structural opportunities at the global level should also not be an excuse for assuming that opportunity automatically produces the capacity to take advantage of them. Barriers to global mobilization may be lower than they were fifty years ago, but the obstacles still remain formidable. Whether labor will succeed depends on the robustness and resilience of the multiple concrete trajectories of global organization, mobilization and contestation that have emerged in the last three decades. 


\section{Concatenated Diversity as a Strategic Response}

Is the labor movement building the mobilizational capacity necessary to seize the new opportunities presented by neoliberal globalization? The answer to this question is anything but simple. If we look at the outcome of individual campaigns the assessment would be negative. Many fail. Many of the successes are partial or subsequently undermined. But, institutional legacies are more important than the outcomes of individual campaigns. Efficacious new institutional forms may emerge from innovative successful campaigns, but even a string of apparent failures may result in the gradual accretion of the institutional foundations for future success.

The idea of 'concatenated diversity' complicates the answer further. If linking diverse organizational forms and strategies is the key to building a global labor movement, then even an assessment of the development of individual forms of organization and contestation is insufficient. An increasingly complex mélange of transnational organizational forms, operating in disparate arenas with disparate forms of contestation, needs to be assessed as an interconnected aggregate.

Labor's response to the challenges of globalization is built on top of a long genealogy of labor movement organizations. Much more than other transnational social movements, the global labor movement is a set of historically layered organizational and institutional forms going back at least 150 years. Earlier organizational forms have evolved; new forms have been layered on top of them. The layers interact to produce a concatenated mobilizational structure whose overall capacity is not easy to assess. ${ }^{11}$

The current organizational terrain can be divided along at least two dimensions. The distinctive organizational forms associated with different components of global labor mobilization create one kind of distinction. The core of the trade union movement is dominated by organizations with traditional bureaucratic structures that can be diagramed as 'trees.' In contrast, the networked relations among the growing number of labor NGOs are often characterized as having a more horizontal 'rhizomic' structure. The second essential distinction is between organizations whose explicit mandate is transnational, like the ITUC, the GUFs and many labor NGOs, and the national confederations and unions that still anchor most bargaining and campaigns. For both distinctions - trees vs. rhizomes and transnational vs. national - the connections that bridge the differences that are crucial. ${ }^{12} \mathrm{I}$ will start with trees and rhizomes and then move to national-transnational linkages.

\section{CONNECTING TREES AND RHIZOMES}

'Tree' structures offer the reach and simplicity of hierarchical coordination, which is why the organizational charts of almost all modern organizations, from corporations to government agencies to armies to political parties, are structured as trees. Multiple levels with those located at each level in charge of multiple subordinates enable such organizations to coordinate the actions of large numbers through a simple 'chain of command'. Like the parties with which they have been allied and the corporations that they fight, the labor 
movement has traditionally used tree-like organizational structure to gain the power to coordinate large numbers.

Rhizomes are network structures in which nodes (individuals or organizations) have multiple connections and are not 'under the command' of other nodes. Rhizomic networks are seen as more agile and flexible, more immediately responsive to new circumstances, trading overall coordination for the ability of individual nodes or subparts of the network take timely initiatives. ${ }^{13}$ The networks of ties among Labor NGO's, in which no single organization is in a position to give orders to other organizations and connections are often based on personal ties, fit the rhizomic model.

Blanket arguments in which the success of the labor movement depends on whether it can migrate from bureaucratic tree-like structures to more rhizomic organizational forms are almost certainly wrong. Which organizational form works best depends on the context and the kind of opponent being confronted. Even more important, the two organizational forms are often interconnected. Tree-like organizations rely on rhizomic networks of individual ties and alliances to build connections among them. Rhizomic networks depend on the support of tree-like organizations to give them clout in battles with hierarchically organized opponents. Traditionally structured labor movement organizations operate side by side with informal, 'rhizome-like' decentralized networks of NGO's.

The real question is how these organizational structures, individually and in combination, contribute to the overall mobilizational capacity of the global labor movement. Have emergent rhizomic networks enhanced overall mobilizational capacity? Are traditional tree-like organizations falling into ineffectual senescence or responding strategically? Do they appear more or less vital than they did prior to the neoliberal era? Most important, are interconnections between the two organizational forms creating new synergies? I will start by reviewing some assessments of formal international labor organizations. Then I will introduce some perspectives on what have been called (e.g. Kidder 2002: 270) 'new transnational labor networks', TANs for short. ${ }^{14}$

The formal structures of transnational unionism are the obvious organizational embodiments of the global labor movement. Efforts to form transnational confederations of national unions go back at least to the nineteeth century and the First International. Despite occasional moments of promise, such as the brief flourishing of the World Federation of Trade Unions as a unified confederation in the immediate post World War II period, conflicts among competing federations have been as prominent in the histories of formal global labor organizations as concerted efforts to countervail the power of capital. ${ }^{15}$

Relative to the historical record, the recent evolution of these formal structures looks promising. The 2006 merger of the World Confederation of Labor and the International Confederation of Free Trade Unions to form the International Trade Union Confederation (ITUC) replaces a structure fractured by Cold War politics with the possibility of a unified strategic actor.16 The move to rename the International Trade Secretariats (ITSs), calling them Global Union Federations (GUFs) instead, reflected recognition that it is not so much trade itself as the global production networks that underlie it that must be restructured if workers interests are to be protected. ${ }^{17}$ The accompanying organizational consolidation 
reflected appreciation that global corporations operate across a range of sectors, and labor organizations must encompass a similar range. Efforts at restructuring aside, however, most would argue that the formal union structures at the global level remain under-resourced and underdeveloped as instruments for contesting the power of transnational capital.

Critiques of global union confederations (ITUC and previous incarnations) are not hard to find. Alan Howard (2007) describes them as 'rigid and not necessarily coherent' organizational structures in which 'all too often the energy and creativity of many talented and selfless people are smothered by a lethal bureaucratic mentality'. Lerner (2007a: 32) argues that the ICFTU [ITUC] and most GUFs are 'underfunded with limited resources and capacity' because of 'a lack of fundamental commitment from national affiliates to provide resources and support global activities'. Jakobsen (2001) offers a biting critique of the formal international structures of global labor - as operating not just on the basis of trees but on the basis of overly centralized 'Leninist' organizational models that have allowed the persistence of leadership disproportionately dominated by trade unionists from the North. The substantive reflection of these organizational structures, Jakobsen argues, is the absence of any real strategy to address the most urgent problems of millions of workers in the Global South, which begin with lack of access to formal employment.

Even in the restricted realm of furthering the interests of the regular employees of multinational corporations, the capacity of the ITUC and the Global Union Federations (GUFs) is limited. The mid twentieth century dream that GUFs might become agents of international collective bargaining by forming 'World Company Councils' has been abandoned in favor of focusing on getting companies to agree to 'International Framework Agreements', which are essentially voluntary company-specific agreements to abide by core labor standards. ${ }^{18}$

If early dreams of GUFs as global bargaining agents have not been realized, they continue, nonetheless, to provide important infrastructural support for a variety of specific campaigns, global and local. Transnational campaigns still depend primarily on local and national unions, but support from the GUFs can play a key catalytic role. From the IUF's support of Coca Cola workers in Guatemala in the 1980's (Kidder 2002) to the ITGLWF's recent role in supporting apparel workers in Central America, the GUF's have proved themselves to be valuable resources for local unions fighting global companies (see Rodríguez-Garavito 2007). The most impressive of these campaigns - the ITF's 'flags of convenience' campaign - did everything a global campaign could be expected to do: brought together workers transnationally, bridged the North-South divide, and actually changed the structure of the labor market for merchant seamen (see Lillie 2010).

The Global Confederations are even more insulated from efforts to bargain with transnational employers than the GUFs. Yet, here again, the state of global organization is more promising than it has been for decades. The shift of U.S. unions away from their Cold War, chauvinist, anti-communist, some would say imperialist, mid-twentieth century stance has removed a major obstacle to the construction of labor internationalism. In comparison to the 1970's when U.S. unions refused to participate even in the anti-communist ICFTU, today's ITUC is in an enviable position. 
Progress aside, GUFs and the ITUC are not the global bargaining powers that Lerner would like to create. Even if they were to gain the resources necessary to become more effectively engaged in contesting the power of global capital, these traditional tree-like organizations are unlikely to be, in themselves, the solution to labor's quest to globalize. Tree-like organizations work best in conflicts with similarly organized large-scale organizations, as tools for magnifying the power of workers that already have 'structural power' grounded in formal employment with large, stable employers. As structural power and formal employment are increasingly undermined by neoliberal globalization, the need for alternative forms of power and therefore alternative forms of mobilization increases proportionately.

In compensation, both the shifting structure of employment in the direction of services and the informalization of previously formal employment relations have created new possibilities for building transnational alliances that connect labor with other groups in civil society. Employers' blatant violations of the values of human dignity, universal human rights, and citizenship rights - all of which the dominant neoliberal ideology purports to defend - can be used, at least in principle, to broaden the array of workers' political allies. ${ }^{19}$ In short, there are new opportunities for connecting rhizomic networks of transnational NGOs to traditional union trees.

The 1990's witnessed the most explosive growth of the form. Transnational labor networks became an increasingly prominent instrument in the fight for labor rights. The 'Teamsters and Turtles' images from Seattle etched these new possibilities into the public imagination. The combination of thousands of trade unionists and the innovative tactics initiated by hundreds of NGO activities demonstrated the political advantages of the alliance..$^{20} \mathrm{~A}$ variety of $\mathrm{NGOs}$ joined with traditional labor movement organizations to champion the cause of workers in the Global South across a range of sectors from truck bodies in Mexico (Williams 2003) to footwear in Vietnam (O'Rourke 2004) to bananas in Central America (Frank 2005, Frundt 2002, 2007).

Apparel commodity chains linking producers in Mexico and Central America to consumers of branded apparel in the United States were archetypical locations for these transnational networks. Students were the archetypical links. A series of transnational campaigns demonstrated the power of normative appeals to connect workers in the South with consumers in the North via threats to devalue profit-magnifying brand names and restrict access to high margin market niches, like university apparel. ${ }^{21}$

Anner (2000) nicely illustrates the impact of the form by chronicling the dramatic shift of media perceptions of the main actors in struggles against sweatshops during the 1990's. In 1993 sweatshop struggles were rarely reported in major media, and the main actors credited with fighting against sweatshops were unions. By 1999, the number of articles was an order of magnitude larger and the most prominently mentioned protagonists were students, followed by NGO's, with unions getting a fraction of the mentions garnered by students.

For some (e.g. Munck 2002) the addition of these new forms and the engagement of new actors heralded a new capacity of labor transnationalism to play a leading role in an 
encompassing Polanyian coalition of social forces resisting neoliberal globalization. But, by the beginning of the new millennium, analysis of the limitations of TAN strategies and structures was more prominent. Too many campaigns ended in defeat and too many of the best strategized, hardest fought victories were subsequently undercut when plants closed down, leaving workers with no jobs at all.

Heather Williams concluded her analysis of the Han Young campaign, which ended in a 'long, slow defeat' despite a strong transnational support network and extraordinary militancy on the part of the local workers, by reminding TAN enthusiasts that (2003: 544) 'the hard fact of the matter is that some of the most important cases have yielded paltry results.' Cesar Rodríguez-Garavito (2007: 137), concludes his exceptionally systematic investigation of transnational campaigns in the apparel industry by warning that, in the absence of broader, industry and country-wide political and regulatory transformations, even iconic victories may prove fleeting.'

Recognizing the limitations of the power of new network forms is essential, but defeats in individual campaigns should not obscure the long-term institutional building that has continued despite the defeats. Campaigns built around transnational NGO networks are not 'magic bullets', but neither does the proportion of campaigns won and lost during the early years of experimentation with new forms properly measure their promise. Each campaign, won or lost, is a fertile site for institutional learning. New strategies and new forms of institutional design depend, not just on learning within TAN networks, but also on the evolving strategies of other actors in the global labor movement.

Rodríguez-Garavito's (2007) analysis of apparel campaigns, which is one of the few pieces of research that looks systematically at the aggregation of a large number of campaigns, flags the possibility of longer-term effects. Rodríguez-Garavito's systematic mapping of the participants in transnational apparel campaigns reveals an interesting and somewhat unexpected picture of the transnational apparel network. This is clearly a network that links traditional union trees with smaller NGOs characteristically associated with rhizomic networks. The venerable AFL-CIO (through its Solidarity Center) is involved in a larger portion of the campaigns than USAS and the WRC combined. ${ }^{22}$ The apparel GUF (the ITGLWF) and UNITE, which represented U.S. apparel workers, are each involved in more campaigns than USAS, the WRC, or the Maquila Solidarity Network. ${ }^{23}$ These numbers should not be taken to negate the crucial role of labor NGOs in these campaigns, but they do indicate that this particular mobilizational structure involves a tight and intimate bond between the world of trees (traditional labor organizations) and the world of rhizomes (newer, smaller transnational NGOs).

Evidence of cumulative institutional learning is the most promising feature of this particular arena of transnational mobilization. For example, the 2009 campaign for union recognition in the Russell Athletics factories in Honduras built on the experience of prior campaigns and used a similar set of transnational ties with significantly greater effectiveness. Likewise, the BJ\&B plant in the Dominican Republic, where a hard-fought, carefully strategized campaign victory was wiped out by the plant's closure (see Rodriguez 2007), later re-emerged as part of an innovative new project brokered by the WRC in which Knights 
Apparel will produce 'sweat-free apparel'. Even more potentially significant is the WRC's plan to institutionalize the enforcement of apparel codes through a 'Designated Suppliers Program' that would encompass a growing share of the university apparel niche. ${ }^{24}$ Nor should this institutional learning be dismissed as relevant only to the university apparel niche. Wetterberg (2010) traces the way in which organizers have learned how to transplant the models developed in the apparel sector to other arenas.

Celebration would, unfortunately, be premature. Analyses of transnational mobilization rarely consider the relative weight of transnational campaigns in the overall panorama of labor struggles. Wetterberg's earlier (2006) work is one of the few exceptions. Her analysis of a systematic sample of strikes in the Global South during the period 19982003, finds only a tiny proportion directly involve transnational linkages. In short, there is ample evidence that effective tools for transnational contestation are being developed, but it is even clearer that the organizational resources, of all types, that are being devoted to the global campaigns would need to expand exponentially if labor is to succeed at the global level.

As long as global labor organizations remains so badly under resourced, expanding the impact of transnational mobilization on workers' fortunes depends above all on building synergistic connections among national confederations and unions in different countries and regions. This in turn depends on the extent to which major national unions and confederations recognize the value of building such connections. National-level organizations remain the most important players in the global labor movement. The union movement's formal organizations at the global level have only a small fraction of the resources available to major national unions and confederations in the North. The resources available to the TANs are an even smaller fraction. Unless the most powerful national unions and confederations in the North and the major countries of the South give transnational campaigns and institutions a more central place on their agendas, global solidarity cannot grow.

\section{NATIONAL UNIONS AND TRANSNATIONAL MOBILIZATION}

During the second half of the twentieth century, the prevalence of insular, chauvinistic orientations on the part of the most powerful national labor organizations of the global North was the most debilitating weakness in the effort to build a global labor movement. Major labor confederations in the South were also prone to strategies that marginalized transnational strategies in favor of reliance on corporatist alliances with local states, but it was the absence of full commitment on the part of national organizations in the North, especially in the United States, that was most damaging.

Over the course of the last forty years, neoliberal globalization has helped break down this impediment. As it became clear in the North that even politicians sympathetic to labor were not going to try to use their declining power over flows of goods and capital to protect local workers, even traditional trade unions began to see the necessity of building transnational alliances. ${ }^{25}$ Likewise, in the South, belief dimmed that corporatist state-labor alliances would protect labor's interests. ${ }^{26}$ 
There has always been a subset of unions interested in forging transnational alliances, for a combination of structural and ideological reasons. Seamen and dockworkers are structurally prone to being transnationalists. ${ }^{27}$ In other cases, ideology is the driver. The United Electrical Workers, whose long-standing left orientation helped propel its alliance with the FAT in Mexico, is an iconic case in point (see Kay 2005, 2010). Ideology is a prime driver of transnational responses in the South as well as the North, as Anner's (2003, 2004) work on Argentina, Brazil and Central America illustrates nicely. ${ }^{28}$ In Brazil, for example, the conservative Força Sindical evinces little interest in transnational strategies, while CUT affiliated unions are much more open to transnational strategies (see Anner 2004).

The question is whether the neoliberal era is expanding the scope of transnationalism to unions whose structural position and ideological propensities have led them to be nationalist in the past. The apparel industry campaigns in Mexico and Central America that have already been discussed point toward a positive answer. The willingness of the AFL-CIO and its affiliates to become involved in alliances with Central American groups that they might well have labeled anti-democratic Communists 30 years earlier is a dramatic shift from the 'bad old days', the literally murderous consequences of the activities of the American Institute for Free Labor Development turned the idea of hemispheric labor solidarity into a tragic farce. ${ }^{29}$ UNITE's gradual shift from placing its bets on protectionism to becoming a key participant in the transnational networks of the anti-sweatshop movement in the first half of the 1990's is a good specific example of how the neoliberal era has shifted the strategies of national unions (see Rodríguez-Garavito 2007:143).

Viewed in a historical lens, the current level of solidarity between North American unions and their Latin American counterparts is extraordinary. ${ }^{30}$ Jakobsen (2001) even suggests that ORIT, ${ }^{31}$ the regional confederation that brings together unions of the Western hemisphere, which was once a model of Northern domination, can now offer the new ITUC some lessons in how organizational structures can be changed to increase the effective representation of the global South.

The search for help vis-à-vis intransigent employers in the labor-hostile environment of the U.S. has increasingly pushed U.S. unions to explore transnational alliances. The International Brotherhood of Teamsters' European campaign during the 1997 strike against UPS is a case in point (see Banks and Russo 1999, Clawson 2003: 155-57). Likewise, transnational collaboration with European unions played a key role in the United Steel Workers' dramatic victory against the Ravenswood Aluminum Company (see Juravich and Bronfenbrenner 1999, Herod 2001). Even unlikely national unions, like Lerner's SEIU, are embracing transnational strategies. Perhaps most interesting are the USW's recent collaborations with the CUT (Brazil) chemical workers in the BASF network and with CUT metal workers in the 2007 campaign against Gerdau's Ameristeel subsidiary (Gray 2009). In both cases, "reverse whipsawing" involved Brazilian workers using their more labor friendly national context to help U.S. workers deal with their exceptionally hostile local terrain.

National union confederations are also part of the transactional mix. European confederations like the FNV of The Netherlands, DGB of Germany, LO-Norway, and 
SASK-Finland are involved in a range of projects in the global south, often projects designed to monitor the local activities of European multinationals or enforce international framework agreements. The AFL-CIO's Solidarity Center has become an important actor in new transnational labor networks, not only in Central America but also in Cambodia. ${ }^{32}$

National unions and confederations in the South have also begun to complement their affiliations with global confederations by building additional transnational links. SIGTUR (Southern Initiative on Globalization and Trade Union Rights) is an oft-cited case in point (Lambert and Webster 2003, O'Brien 2006, Webster, Lambert and Benzuidenhout 2008). SIGTUR brings together national unions and confederations from Asia plus South Africa, Brazil and Australia to share perspectives on strategy and mobilizes members to support campaigns in each other's countries, thus providing a way for unions in the Global South to coordinate without necessarily involving a global confederation or one of the GUFs. ${ }^{33}$ It is a nice organizational embodiment of the conviction of the most active national confederations of the Global South (CUT, COSATU and KCTU) that labor must build a transnational movement. ${ }^{34}$

New orientations on the part of national unions, like the concatenation of diverse organizational forms, are still incipient in terms of their ability to counter the offensive from global capital and its political allies. Nonetheless, the gradual accretion of experience and institution building and the continual emergence of innovative new cases point toward an ascendant arc of transnational labor mobilization rather than the sort of precipitous decline projected in the nemesis thesis.

\section{Is it Labor's Turn to Globalize?}

Where does the case for 'labor's turn to globalize' stand? Surprisingly, comparisons to the 'pre-neoliberal era' suggest positive trajectories for each of the elements of labor's global efforts. None look moribund. The GUFs have been consolidated. Transnational networks of labor NGOs have emerged as a new tool in labor's global repertoire. The global confederation is not distracted by internecine warfare. In key national contexts, especially in the Western Hemisphere, national unions are more oriented toward building global solidarity than they have ever been.

None of these individual elements will carry the weight of confronting global capital on its own. Their promise lies in interconnection, in what I have called 'concatenated diversity'. Labor's ability to globalize depends, not on the success of any single organizational form or strategy, but on the ability of the movement to interconnect different forms in strategically effective ways. Tree-like bureaucratic organizations and rhizomic networks, national unions and Global Unions each make distinctive contributions to global campaigns. The question is whether leaders and organizers, each embedded in their own specific organizational forms, will be able to appreciate the necessity of a multiform movement and build on the beginnings already in place. 
Can the concatenated diversity of a global labor movement be brought to bear with sufficient effect to bring greater dignity, better working conditions and improved material circumstances to the world's workers? Anyone claiming a definitive answer to this question is suspect, but some claims are reasonable. Neoliberal globalization has not paralyzed labor's efforts to go global. Advances in the global arena may well be insufficient to counter the multi-level assault being launched against labor by capital and its allies in the state. But, using 'neoliberal globalization' as the catchall explanation for defeats at the local and national level is a mistake.

Rather than being labor's Achilles heel, the global arena has the potential to make a positive contribution to local and national contestation. Neoliberal globalization has increased that potential. Realizing the potential depends on shifting the discussion from lamentations over a supposed structural logic of impossibility to a debate focused on strategies and structures, a debate that follows the Cardoso and Faletto approach to politics under difficult circumstances with which we began, one aimed at facilitating 'collective action guided by political wills that make work what is structurally barely possible'.

\section{NOTES}

${ }^{1}$ This article, and the presentations from which it was derived, have benefitted from constructive critiques and suggestions from too many people to fully acknowledge them all here, but I would be remiss if I did not mention at least a few. Margaret Keck's responses to a preliminary version were a key incentive for revision. Chris Tilly and his colleagues at UCLA provided valuable intermediary feedback. Pablo Gaston's close readings of the current version were crucial. Two anonymous reviewers for this journal provided invaluable feedback on an initial submission. Andrew Schrank and Charlie Eaton provided an additional set of valuable insights on the revised version.

${ }^{2}$ The intensity of resistance in practice is captured in the grisly statistic on murdered trade unionists just released by the ITUC in its Annual Survey of Trade Union Rights [http://www.ituc-csi.org/ituc-annual-survey.html] which found a $30 \%$ increase in the number killed.

${ }^{3}$ Michael Burawoy's (2010:302) polemic, which argues for 'uncompromising pessimism' and dismisses my earlier work on 'counter-hegemonic globalization' (Evans, 2008) as false optimism that 'clutches at straws', is one of the most effectively articulated versions of this position. For another version see Stephen, 2009.

${ }^{4}$ In this same tradition, Albert Hirschman (1971) offers an even more impassioned intellectual defense of exercising a 'bias toward hope'. 
${ }^{5}$ For a discussion of 'whipsawing', see Armbruster (1995).

${ }^{6}$ Tilly's thesis depends on a view of contemporary globalization similar to the one taken here, i.e. that the expansion of the power of private capital in conjunction with the increasing ideological sway of Anglo-Saxon liberalism are the predominant features of the global political economy in the neoliberal era. If one were to adopt what Bowles (2010) calls a 'multi-centered' statist view, then a quite different political analysis would be in order.

${ }^{7}$ Obviously the process is iterative. If successful labor mobilization creates states that are more effective and more responsive, then such states are likely to facilitate further mobilization.

${ }^{8}$ For an historical discussion of the exceptional hostility of the state to labor in the United States, see Voss (1993). Perhaps not surprisingly, given this historical legacy, state-labor relations in the United States look more like the Global South than they do like European Social Democracy (cf. Fantasia \& Voss 2004).

'Indeed, some analyses of the state's role vis-à-vis labor suggest that in Latin American countries, labor laws have overall become more favorable to labor in the neoliberal era (e.g. Murillo \& Schrank).

${ }^{10}$ See Seidman (2007) and Kolben (2010) for analyses of the potential negative impact of 'rights-based' arguments for the labor movement's ability to build collective agency.

${ }^{11}$ Munck (2002) and Webster, Lambert and Benzuidenhout (2008: 193) emphasize the succession of forms in which an 'old labor internationalism' is replaced by a 'new labor internationalism'. While the emergence of new forms and strategies is critical to any possibility of success, a full analysis must take into account the persistence (and possible revitalization) of old structures along with the emergence of new forms.

${ }^{12}$ Munck (2010, figure 1) presents a map of the global labor movement with two dimensions, one of which is geographic scope. He does not, however, focus on the interconnections among different organizational forms.

${ }^{13}$ In some visions, trees are outmoded in the modern world. Castells (1996) provides an analysis along these lines. Hardt and Negri's (2000) vision of the 'multitude', in which trees are fully outmaneuvered by an ever-shifting web of rhizomic relationships whose capillary power is amorphous but immense, is a more extreme example.

${ }^{14}$ The acronym TAN actually stands for transnational advocacy networks and was coined by Keck and Sikkink in their classic 1997 book. Keck and Sikkink neglected to analyze transnational labor networks, but the new transitional labor networks would seem to fit the TAN model. 
${ }^{15}$ See Stevis and Boswell (2008, Chapter 3) for a concise summary of the evolution of international confederations.

${ }^{16}$ The World Federation of Trade Unions still exists as a separate global confederation; it is clearly in senescence and not a source of serious conflict.

${ }^{17}$ In a further terminological shift, the appellation 'Global Unions' is now applied to both the GUF's and the ITUC (plus TUAC).

${ }^{18}$ For a discussion of both the earlier movement for World Company Councils and more recent efforts to expand International Framework Agreements see Stevis and Boswell, 2008: chapter 5. See also Gallin (2008) for a current assessment of the role of IFAs and Levinson (1972) for a historical view.

${ }^{19}$ In Chun's terms $(2006,2009)$, using 'symbolic leverage' to build 'associational power'.

${ }^{20}$ Clawson (2003: 151) captures the advantages of the combination perfectly with quote from a local labor leader who says, 'The Labor movement basically piggy-backed on the courage of the young environmentalists and anti-sweatshop and church activists ... Then again, without the tens of thousands of union members, it would have been easier to write off the young protesters as flakes...'.

${ }^{21}$ See, for example, Wetterberg (2006).

${ }^{22} \mathrm{USAS}=$ United Students against Sweatshops; WRC = Workers Rights Consortium.

${ }^{23}$ Like the ITGLWF (whose role in transnational apparel campaigns has already been mentioned), other GUFs have become involved in 'tree-rhizome' strategies, promoting networks of widely scattered local activists, as in the case of ICEM and the Rio Tinto Network.

${ }^{24}$ See http://www.workersrights.org/RussellRightsViolations.asp and http://www.workersrights.org/dsp/. See also Wetterberg (2010).

${ }^{25}$ The Clinton administration in the U.S. is the iconic example. This is not, of course, to say that powerful states in the North have become unwilling to selectively protect wellconnected segments of capital. See Fairbrother's (2006, 2007) analysis of 'neoliberal mercantilism' in the U.S.

${ }^{26}$ The declining efficacy of the CTM-PRI alliance in Mexico is a prime example (see Kay 2004, 2005). 
${ }^{27}$ The construction of transnational solidarity among European dockworkers is an archetypal example. See Turnbull (2000, 2006 and 2007). The ILWU in the U.S. is also a good example. See Clawson (2003: 157) for the interesting case of the ILWU's student mediated solidarity with Liverpool dockers.

${ }^{28}$ See also Anner et al (2006).

${ }^{29}$ See Sims (1992) for an historical account. Some, like Scipes (2010) argue that the old ways continue, but this is now a minority view.

${ }^{30}$ Cesar Rodriguez (2007: 68) offers a quote from Guatemalan unionist Homero Fuentes, which captures the transformation evocatively. Fuentes says, "When I stepped into the AFLCIO offices for a meeting in the mid-1990s, I couldn't help but think about life's twists and turns. There I was, inside the belly of the beast that had put me and my fellow independent unionists through so much hardship during the Guatemalan war and the Cold War years. This time around I was being welcome, not persecuted. It was an eerie feeling'.

${ }^{31}$ Organización Regional Interamericana de Trabajadores, called since the formation of the ITUC, Confederación Sindical de los Trabajadores y Trabajadoras de las Americas/Trade Union Confederation of the Americas.

${ }^{32}$ In Rodriguez's sample (2007: 153), restricted to campaigns carried out between groups in North America, Central America and the Caribbean, activists from the Solidarity Center participated in more transnational campaigns than any other single organization.

${ }^{33}$ SIGTUR affiliates include trade unions and national confederations from Korea, Thailand, the Philippines, India East Timor, Bangladesh, Sri Lanka, Pakistan, Australia, Nepal, Burma, Cambodia, Brazil, South Africa, with the 2008 Congress held in India and the 2010 Congress in Brazil. For a critical assessment of SIGTUR, see Waterman (2004).

${ }^{34}$ The ACFTU (All China Federation of Trade Unions) still remains, of course, largely isolated from the global labor movement and therefore the biggest question mark in any analysis of the trajectory of national confederations. Likewise, India is an ambiguous case. For a recent discussion of the complexities of the Indian labor movement's global ties, see Hensman (2010). 


\section{REFERENCES}

Anner. M. (2000) 'Local and Transnational Campaigns to End Sweatshop Practices', in M.E. Gordon and L. Turner (eds) Transnational Cooperation Among Trade Unions (pp. 238-255). Ithaca: Cornell University Press.

Anner, M. (2003) 'Industrial Structure, The State and Ideology: Shaping Labor Transnationalism in the Brazilian Auto Industry', Social Science History 27(4): 603634.

Anner, M. (2004) 'Between Solidarity and Fragmentation: Labor Responses to Globalization in the Americas', Unpublished Ph.D. Dissertation, Cornell University.

Anner, M., Greer, I., Hauptmeier, M., Lillie, N. and Winchester, N. (2006) 'The Industrial Determinants of Transnational Solidarity: Global Inter-union Politics in Three Sectors', European Journal of Industrial Relations 12(1): 7-27.

Banks, A. and Russo, J. (1999) 'The Development of International Campaign-based Network Structures: A Case Study of the IBT and ITF World Council of UPS Unions', Comparative Labor Law and Policy Journal 20(4): 543-568.

Bowles, P. (2010) 'Globalization's Problematic for Labor: Three Paradigms', Global Labor Journal 1(1): 12-31.

Bronfenbrenner, K. (ed) (2007) Global Unions: Challenging Transnational Capital Through Cross-border Campaigns. Ithaca: Cornell University-ILR Press.

Burawoy, M. (2010) 'From Polanyi to Pollyanna: The False Optimism of Global Labor Studies', Global Labour Journal 1(2): 301-313.

Cardoso F.H., and Faletto, E. (1979) Dependency and Development in Latin America. Berkeley: University of California Press.

Castells, M. (1996) The Rise of the Network Society. Oxford: Blackwell.

Chun, J.J. (2009) Organizing at the Margins: The Symbolic Politics of Labor in South Korea and the United States. Ithaca: Cornell University-ILR Press.

Chun, J.J. (2005) 'Public Dramas and the Politics of Justice: Comparison of Janitors' Union Struggles in South Korea and the United States', Work and Occupations 32(4): 486503. 
Clawson, D. (2003) The Next Upsurge: Labor and the New Social Movements. Ithaca: Cornell University-ILR Press.

Evans, P. (2008) 'Is an Alternative Globalization Possible?' Politics \& Society 36(2): 271-305.

Evans, P. (1997) 'The Eclipse of the State? Reflections on Stateness in an Era of Globalization', World Politics 50(1): 62-87.

Evans, P. and Anner, M. (2004) 'Building Bridges Across a Double-divide: Alliances Between U.S. and Latin American Labor and NGOs', Development in Practice 14(12): 34-47.

Evans, P. and Finnemore, M. (2001) 'Organizational Reform and the Expansion of the South's Voice at the Fund', G-24 Discussion Paper Series (no. 15, December), UNCTAD and Harvard University Center for International Development.

Evans, P. and Staveteig, S. (2009) 'The Changing Structure of Employment in Contemporary China', in D. Davis and F. Wang (eds) Creating Wealth and Poverty in Post-socialist China (pp. 69-82). Stanford: Stanford University Press.

Fairbrother, M.H. (2007) 'Making Neoliberalism Possible: The State's Organization of Business Support for NAFTA in Mexico', Politics and Society 35(2): 265-300.

Fantasia, R. (1989) Cultures of Solidarity: Consciousness, Action, and Contemporary American Workers. Berkeley: University of California Press.

Fantasia, R. and Voss, K. (2004) Hard Work: Remaking the American Labor Movement. Berkeley: University of California Press.

Frank, D. (2005) Banananeras: Women Transforming the Banana Unions of Latin America. Cambridge: South End Press.

Frundt, H.J. (2002) 'Central American Unions in the Era of Globalization', Latin American Research Review 37(3): 7-55.

Frundt, H.J. (2007) 'Organizing in the Banana Sector', in K. Bronfenbrenner (ed), Global Unions: Challenging Transnational Capital Through Cross-border Campaigns (pp. 99116). Ithaca: Cornell University Press.

Gallin, D. (2008) 'International Framework Agreements: A Reassessment', in K. Papadakis (ed), Cross-border Social Dialogue and Agreements: An Emerging Global Industrial Relations Framework? (pp. 15-42). Geneva: ILO. 
Gray, C. (2009) Metalúrgicos sem Fronteiras: Building a global Union at Gerdau. Unpublished MA Thesis, Cornell University.

Hardt, M. and Negri, A. (2001) Empire. Cambridge: Harvard University Press.

Harvey, D. (2005) A Brief History of Neoliberalism. New York: Oxford University Press.

Hensman, R. (2010) 'Labour and Globalization: Union Responses in India', Global Labour Journal 1(1): 112-131.

Herod, A. (2001) 'Labor Internationalism and the Contradictions of Globalization: Or, Why the Local is Sometimes Still Important in a Global Economy', Antipode 33(3): 407-426.

Hirschman A. (1971) A Bias for Hope. New Haven, CT: Yale University Press.

Howard, A. (2007) 'The Future of Global Unions: Is Solidarity Still Forever?', Dissent (Fall).

Jakobsen, K. (2001) 'Rethinking the International Confederation of Free Trade Unions and its Inter-American Regional Organization', Antipode 33(3): 363-383.

Juravich, T. and Bronfenbrenner, K. (1999) Ravenswood: The Steelworkers' Victory and the Revival of American Labor. Ithaca: Cornell University-ILR Press.

Kay, T. (2010) [Forthcoming]. NAFTA and the Politics of Labor Transnationalism. Cambridge: Cambridge University Press.

Kay, T. (2005) 'Labor Transnationalism and Global Governance: The Impact of NAFTA on Transnational Labor Relationships in North America', American Journal of Sociology 111(3): 715-756.

Keck, M.E. and Sikkink, K. (1998) Activists Beyond Borders: Advocacy Networks in International Politics. Ithaca: Cornell University Press.

Kidder, T.G. (2002) 'Networks in Transnational Labor Organizing', in S. Khagram, J.V. Riker and K. Sikkink (eds), Restructuring World Politics: Transnational Social Movements, Networks, and Norms (pp. 269-298). Minneapolis: University of Minnesota Press.

Kolben, K. (2010) 'Labor Rights as Human Rights?', Virginia Journal Of International Law 50(2): 450-484. 
Lambert, R. and Webster, E. (2003) 'Transnational Union Strategies for Civilizing Labor Standards', in R. Sandbrook (ed) Civilizing Globalization: A Survival Guide (pp. 221236). Albany: State University of New York Press.

Lerner, S. (2007a) 'Global Unions: A Solution to Labor's Worldwide Decline', New Labor Forum 16(1): 22-37, 156.

Lerner, S. (2007b) 'Global Corporations, Global Unions', Contexts 6(3): 16-22.

Levinson, C. (1972) International Trade Unionism. London: Allan and Unwin.

Lillie, N. (2010) A Global Union for Global Workers: Collective Bargaining and Regulatory Politics in Maritime Shipping. New York: Routledge.

Meltzer, A. (2000) Report of the International Financial Institutions Advisory Commission. Washington, DC: United States Congress.

Munck, R. (2002) Globalization and Labour: The New 'Great Transformation. London: Zed Books.

Munck, R. (2010) 'Globalization and the Labor Movement: Challenges and Responses', Global Labor Journal 1(2): 218-232.

O'Brien, R. (2000) 'Workers and World Order: The Tentative Transformation of the International Union Movement', Review of International Studies 26(4): 533-555.

O'Rourke, D. (2004) Community-driven Regulation: Balancing Development and the Environment in Vietnam. Cambridge: MIT Press.

Rodriguez-Garavito, C.A. (2007) Sewing Resistance: Transnational Organizing, Global Governance, and Labor Rights in the U.S.-Caribbean Basin Apparel Industry (19902005). Unpublished Ph.D. Dissertation, Department of Sociology, University of Wisconsin, Madison, WI.

Rodriguez-Garavito, C.A. (2005) 'Global Governance and Labor Rights: Codes of Conduct and Anti-sweatshop Struggles in Global Apparel Factories in Mexico and Guatemala', Politics and Society 33(2): 203-233.

Scipes, K. (2010) AFL-CIO's Secret War Against Developing Country Workers: Solidarity or Sabotage? Lanham, MD: Lexington Books. 
Seidman, G. (2007) Beyond the Boycott: Labor Rights, Human Rights, and Transnational Activism. New York: Russell Sage Foundation.

Silver, B.J. (2003) Forces of Labor: Workers' Movements and Globalization Since 1870. Cambridge: Cambridge University Press.

Silver, B.J. and Zhang, L. (2009) 'China as an Emerging Epicenter of World Labor Unrest', in H.F. Hung (ed) China and the Transformation of Global Capitalism (pp. 174-187). Baltimore: John Hopkins University Press.

Sims, B. (1992) Workers of the World Undermined: American Labor's Role in US Foreign Policy. Boston: South End Press.

Smith, J. (2008) Social Movements for Global Democracy. Baltimore: The Johns Hopkins University Press.

Somers, M. (2008) Genealogies of Citizenship: Markets, Statelessness and the Right to Have Rights. Cambridge: Cambridge University Press.

Stephen, M. (2009) 'Alter-globalism as Counter-hegemony: Evaluating the "Postmodern Prince"', Globalizations 6(4): 483-498.

Stevis, D and Boswell, T. (2008) Globalization and Labor: Democratizing Global Governance. Plymouth: Rowman and Littlefield Publishing.

Tilly, C. (1995) 'Globalization Threatens Labor's Rights', International Labor and Working Class History 47(Spring): 1-23.

Turnbull, P. (2000) 'Contesting Globalization on the Waterfront', Politics \& Society 28(3): 273-97.

Turnbull, P. (2006) 'The War on Europe's Waterfront: Repertoires of Power in the Port Transport Industry', British Journal of Industrial Relations 44(2): 305-326.

Turnbull, P. (2007) 'Dockers Against the Directives: Battling Port Policy on the European Waterfront', in K. Bronfenbrenner (ed), Global Unions: Challenging Transnational Capital Through Cross-border Campaigns. Ithaca: Cornell University-ILR Press.

Voss, K. (1993) The Making of American Exceptionalism: The Knights of Labor and Class Formation in the Nineteenth Century. Ithaca: Cornell University Press. 
Waterman, P. (2001) 'Trade Union Internationalism in the Age of Seattle', Antipode 33(3): 312-336.

Webster, E., Lambert, R. and Bezuidenhout. A. (2008) Grounding Globalization: Labor in the Age of Insecurity. Malden: Blackwell.

Wetterberg, A. (2006) 'Transnational Labor Linkages: Great Expectations but Slim Prospects?', Paper presented at the RC-44 session on Transnational Organising, $16^{\text {th }}$ World Congress of the International Sociological Association, Durban, South Africa 26 July.

Wetterberg, A. (2010) 'The Institutionalization of Labor Self-regulation in the Global Apparel Industry', Ph.D. Dissertation, Department of Sociology, University of California, Berkeley.

Williams, H. L. (2003) 'Of Labor Tragedy and Legal Farce: The Han Young Factory Struggle in Tijuana, Mexico', Social Science History 27(4): 525-550.

Wills, J. (1998). 'Taking on the CosmoCorps? Experiments in Transnational Labor Organization', Economic Geography 74(2): 111-130.

\section{BIOGRAPHICAL NOTE}

Peter Evans is Professor of Sociology and Marjorie Meyer Eliaser Professor of International Studies at the University of California, Berkeley. His work on the comparative political economy of national development is exemplified by his 1995 book Embedded Autonomy: States and Industrial Transformation and a recent series of articles on the ' $21^{\text {st }}$ Century Developmental State'. He has also worked on urban environment politics [Livable Cities, 2001]. For the past several years he has been researching the ways in which social movements can mobilize transnationally to build a 'counter-hegemonic globalization'. Among these movements, the global labor movement is a key actor. 


\section{Appendix}

\section{ACRONYM GLOSSARY}

\begin{tabular}{|c|c|}
\hline ACFTU & All China Federation of Trade Unions \\
\hline AFL-CIO & American Federation of Labor - Congress of Industrial Organizations \\
\hline BASF & Badische Anilin- und Soda-Fabrik (Baden Aniline and Soda Factory) \\
\hline ССР & Chinese Communist Party \\
\hline \multirow[t]{2}{*}{ COSATU } & Congress of South African Trade Unions \\
\hline & $\begin{array}{l}\text { Confderación de Trabajadores de México (Confederation of Mexican } \\
\text { Workers) }\end{array}$ \\
\hline CUT & $\begin{array}{l}\text { Central Unica dos Trabalhadores (Unified Workers' Central) } \\
\text { Deutscher Gewerkschaftsbund (Confederation of German Trade }\end{array}$ \\
\hline DGB & Unions) \\
\hline FAT & $\begin{array}{l}\text { Frente Auténtico del Trabajo (Authentic Labor Front) } \\
\text { Federatie Nederlandse Vakbeweging (Federation Dutch Labour }\end{array}$ \\
\hline FNV & Movement) \\
\hline GUF & $\begin{array}{l}\text { Global Union Federation } \\
\text { International Federation of Chemical, Energy, Mine and General }\end{array}$ \\
\hline ICEM & Workers' Unions \\
\hline ICFTU & International Confederation of Free Trade Unions \\
\hline ILWU & International Longshore and Warehouse Union \\
\hline IMF & International Monetary fund \\
\hline ISI & Import Substitution Industrialization \\
\hline \multirow[t]{2}{*}{ ITF } & International Transport Workers' Federation \\
\hline & $\begin{array}{l}\text { International Textile, Garment and Leather Workers' Federation } \\
\text { (ITGLWF) }\end{array}$ \\
\hline ITS & International Trade Secretariat \\
\hline ITUC & International Trade Union Confederation \\
\hline IUF & International Union of Food Workers \\
\hline \multirow[t]{2}{*}{ KCTU } & Korean Confederation of Trade Unions \\
\hline & Landsorganisasjonen i Norge (Norwegian Confederation of Trade \\
\hline LO -Norway & Unions) \\
\hline MSN & Maquila Solidarity Network \\
\hline \multirow[t]{2}{*}{ NGO } & Non-Governmental Organization \\
\hline & Organización Regional Interamericana de Trabajadores (Inter \\
\hline \multirow[t]{2}{*}{ ORIT } & American Regional Organization of Workers) \\
\hline & Partido Revolucionario Institucional (Institutional Revolutionary \\
\hline PRI & Party) \\
\hline RedLat & $\begin{array}{l}\text { Rede Latino-Americana de Pesquisa em Empresas Multinacionais } \\
\text { (Latin American Network for Multinational Company Research) }\end{array}$ \\
\hline
\end{tabular}


Suomen Ammattilittojen Solidaarisuuekus (Trade Union Solidarity

SASK Centre of Finland)

SEIU Service Employees International Union

SIGTUR Southern Initiative on Globalization and Trade Union Rights

TAN Transnational Action Network

TUAC Trade Union Advisory Committee

TUCA Trade Union Confederation of the Americas

UNITE Union of Needletrades, Industrial and Textile Employees

UPS United Parcel Service

USAS United Students Against Sweatshops

USW United Steel Workers of America

WRC Workers Rights Consortium 